Arch. Dis. Childh., 1965, 40, 284.

\title{
A RELIABLE RAPID SCREENING TEST FOR SULPHATIDE LIPIDOSIS
}

\author{
BY \\ BRIAN D. LAKE \\ From the Department of Morbid Anatomy, The Hospital for Sick Children, Great Ormond Street, London W.C.1
}

(RECEIVED FOR PUBLICATION AUGUST 17, 1964)

The tests devised by Austin (1957) for the detection and isolation of metachromatic material from urine as a screening test for sulphatide lipidosis (metachromatic leucodystrophy) have been shown not to be entirely reliable because of the high incidence of false positives (Helfant, Börgeson, and Hellström, 1962). Even biochemical estimation showing raised amounts of urinary sulphatide cannot be taken as a reliable guide, since increased sulphatide excretion is also found in demyelinating diseases and in normal infants of less than 1 year (Hagberg and Svennerholm, 1960).

We have been using a simpler method than that of Austin for the screening of mentally retarded children, and have found that in 10 cases of sulphatide lipidosis all gave a positive result on urine sediment examination. There have been no false positives in 128 cases examined. The diagnosis was confirmed by rectal and peripheral nerve biopsies (Bodian and Lake, 1963) or by brain biopsy. Two cases in the series have come to necropsy, and together with five other available necropsy cases, the renal deposition of sulphatide was readily demonstrated in frozen sections by the same staining procedure.

\section{Method}

The urine, which must be fresh and preferably not an early morning specimen, is centrifuged at 2,000 3,000 r.p.m. for 10 minutes. The supernatant is decanted, and 6 smears from the sediment are made on glass slides and then fixed in formalin vapour at $60^{\circ} \mathrm{C}$. for one hour. The slides are washed in water and stained at room temperature for 10 minutes in a $1 \%$ aqueous solution of cresyl fast violet (E. Gurr, or Hopkins and Williams), the $p \mathrm{H}$ of which has been adjusted to 3.5-3.6 with acetic acid. The smears are washed in water and mounted in glycerin jelly.

\section{Results}

A positive result is indicated by the presence of brown metachromatic staining material in the cytoplasm of renal epithelial cells (see Table). In all cases of sulphatide lipidosis examined in this series, there has been intracellular brown metachromatic material present. Only intracellular material is to be regarded as positive. Extracellular brown material is often seen and may be related to release of sulphatide in other types of demyelinating process, but it is so often seen that some other explanation is more likely.

\section{TABLE}

\begin{tabular}{c|c|c|c|c}
\hline $\begin{array}{c}\text { No. of } \\
\text { Urines } \\
\text { Examined }\end{array}$ & $\begin{array}{c}\text { No. } \\
\text { Negative }\end{array}$ & $\begin{array}{c}\text { No. } \\
\text { Positive }\end{array}$ & $\begin{array}{c}\text { No. Subsequently } \\
\text { Shown to Have } \\
\text { Sulphatide } \\
\text { Lipidosis }\end{array}$ & $\begin{array}{c}\text { No. of } \\
\text { False } \\
\text { Positives }\end{array}$ \\
\hline 128 & 118 & 10 & 10 & 0 \\
\hline
\end{tabular}

\section{Discussion}

There are two explanations to account for the presence of sulphatide in the urine in sulphatide lipidosis. The first is that it is an excretion phenomenon related to removal of sulphatide from sites of demyelination. The second is that sulphatide lipidosis is a generalized enzymopathy and that wherever sulphatide is metabolized, i.e. in the kidney, accumulation takes place with subsequent excretion. The bulk of evidence supports the latter theory since excess sulphatide is observed in a variety of sites not related to myelinated nerves, i.e. gall-bladder, liver, pancreas, lamina propria of the colon, and the kidney. All myelinated nerves are also affected. Certain organs will become affected at an earlier stage by virtue of a normally high sulphatide metabolism, and as the kidney is always grossly involved it may be possible to provide an early preclinical diagnosis by examination of the urinary sediment. This test may appear positive before a diagnosis is possible by the conventional procedure of biopsy of 
peripheral nerve or rectum. Sulphatide lipidosis is a hereditary disorder and an early diagnosis is of the utmost importance so that the requisite advice may be given to the parents.

\section{Summary}

A simple reliable method for the diagnosis of sulphatide lipidosis is described. Used in conjunction with other urine tests, i.e. phenistix and amino acid chromatography, it is a reliable guide on which to base subsequent investigations of mentally retarded children.
This work was supported by a grant from the Joint Research Board of the Institute for Child Health, Great Ormond Street, W.C.1.

\section{REFERENCES}

Austin, J. H. (1957). Metachromatic form of diffuse cerebral sclerosis. Neurology (Minneap.), 7, 415, 716.

Bodian, M., and Lake, B. D. (1963). The rectal approach to neuropathology. Brit. J. Surg., 50, 702.

Hagberg, B., and Svennerholm, L. (1960). Metachromatic leucodystrophy-a generalized lipidosis. Detection of sulfatides in urine, blood plasma and CSF. Acta paediat. (Uppsala), 49, 690.

Helfant, M. H., Börgeson, M., and Hellström, B. (1962). The value of urinary sediment examination as a screening method in suspected cases of metachromatic leucodystrophy. ibid., 51, 49. 